\title{
Analisis Hubungan antara Sikap Penyelesaian Soal dan Hasil Belajar Mahasiswa Calon Guru Fisika
}

\author{
Hamdani $^{1}$, Syukran Mursyid ${ }^{1}$, Judyanto Sirait ${ }^{1}$, Eugenia Etkina ${ }^{2}$ \\ ${ }^{1}$ Pendidikan Fisika, Universitas Tanjungpura, Pontianak, Indonesia \\ ${ }^{2}$ Graduate School of Education, Rutgers University of New Jersey, New Brunswick, USA \\ Email: hamdani052185@gmail.com
}

\begin{abstract}
This study aims to examine the correlation between students' attitude and approach and achievement that involved 60 pre-service physics teachers of Tanjungpura University. A quantitative approach was applied to gather students' attitude and approach data through problem solving survey (APESOFI) which consists of seven indicators: using representation, the role of the equation, checking the answers, the role of physics concepts, discussion and asking, problem solving strategies, and interested in solving the problem. The results show that the correlation between students' attitude an approach and achievement is $0.24(\mathrm{p}=0.06)$. Furthermore, one of indicator - problem solving strategies and students' achievement - has significant correlation $.33(\mathrm{p}=0.01)$. Also, $70 \%$ of students have the same approach to experts while solving the problem. It indicates the problem solving strategies is one of the aspects that can affect students' success to solve the problems. Accordingly, instructors should facilitate students with various strategies or approaches to problem solving.
\end{abstract}

Keywords: APESOFI, correlation, problem solving strategies.

\begin{abstract}
Abstrak
Penelitian ini bertujuan untuk mengetahui hubungan antara sikap penyelesaian soal fisika dan hasil belajar mahasiswa calon guru fisika tahun pertama program studi Pendidikan Fisika Universitas Tanjungpura yang melibatkan 60 orang. Penelitian kuantitatif digunakan untuk memperoleh data sikap mahasiswa dengan memberikan Angket Penyelesaian Soal Fisika (APESOFI) dengan tujuh indikator: penggunaan representasi, peran matematika dan rumus, memeriksa kembali jawaban, peran konsep, berdiskusi dan bertanya, strategi penyelesaian soal, dan ketertarikan menyelesaikan soal. Kemudian nilai akhir mata kuliah Fisika Dasar dijadikan sebagai data hasil belajar. Hasil analisis data menunjukkan bahwa korelasi antara sikap dan hasil belajar 0,24 dengan $p=0,06$. Selanjutnya, hubungan salah satu indikator yaitu strategi penyelesaian soal dengan hasil belajar menunjukkan korelasi yang signifikan yaitu $0,33(\mathrm{p}=0,01)$. Selain itu, $70 \%$ mahasiswa memiliki sikap yang sesuai dengan strategi yang digunakan ahli dalam menyelesaikan soal. Hal ini mengindikasikan bahwa strategi penyelesaian soal merupakan salah satu yang menentukan keberhasilan mahasiswa dalam menyelesaikan soal. Dengan demikian pengajar atau dosen perlu memfasilitasi mahasiswa dengan beberapa strategi atau pendekatan dalam menyelesaikan soal.
\end{abstract}

Kata-kata Kunci: APESOFI, korelasi, hasil belajar, strategi penyelesaian soal. 


\section{PENDAHULUAN}

Penyelesaian soal atau yang sering disebut pemecahan masalah dan dalam literatur berbahasa inggris disebut problem solving merupakan topik penelitian yang masih menarik dikaji dalam penelitian pendidikan fisika. Mulai dari langkah dan strategi dalam menyelesaikan soal, perbedaan ahli dan pemula dalam menyelesaikan soal, jenis soal yang diberikan, dan pengembangan pembelajaran untuk meningkatkan kemampuan pemecahan masalah atau menyelesaikan soal (Docktor, Strand, Mestre, \& Ross, 2015; Heller, Keith, \& Anderson, 1992; Hestenes, Wells, \& Swackhamer, 1992; Huffman, 1997; Kuo, Hull, Gupta, \& Elby, 2013; Leonard, Dufresne, \& Mestre, 1996; Mestre, Docktor, Strand, \& Ross, 2011). Namun hal ini berfokus pada kemampuan kognitif siswa sebagai langkah untuk membantu siswa dalam menyelesaikan soal atau mendapatkan jawaban yang tepat.

Kemampuan menyelesaikan soal sangat penting dalam belajar fisika karena mahasiswa pasti akan menghadapi ini ketika mereka mendapat tugas kuliah maupun pada saat ujian. Salah satu penilaian dosen dalam mengevaluasi hasil belajar mahasiswa adalah dengan memberikan soal atau tes pada saat kuis, ujian tengah semester maupun akhir semester. Sehingga para ahli memperkenalkan beberapa strategi atau langkah-langkah untuk membantu mahasiswa saat menyelesaikan soal fisika (Docktor et al., 2015; Heller et al., 1992; Leonard et al., 1996). Hal lain yang tidak kalah menarik adalah dari sisi afektif mahasiswa ketika menghadapi soal baik ketika mengerjakan soal latihan atau pekerjaan rumah maupun ketika menghadapi ujian (ujian tengah semester dan ujian akhir).

Pandangan siswa terhadap fisika merupakan salah satu faktor yang mempengaruhi keberhasilan siswa dalam belajar fisika (Elby, 2001; Hammer, 1994). Sebagai contoh, ketika mahasiswa senang belajar materi fisika, mereka akan mendapat nilai yang baik ketika pada saat ujian. Disamping itu, pandangan mahasiswa terhadap fisika mempengaruhi bagaimana mereka mengevaluasi belajarnya (May \& Etkina, 2002). Misalnya, ketika mahasiswa punya pandangan bahwa belajar fisika tidak sekedar belajar rumus, mereka akan berusaha memahami konsep fisika yang dipelajari dan menggunakan konsep tersebut ketika saat mengerjakan soal. Ding dan Zhang (2016) juga melakukan penelitian tentang pandangan calon guru fisika terhadap belajar fisika dan diperoleh bahwa pandangan mereka berubah diawal kuliah dan meningkat ketika akan menyelesaikan kuliah.

Dengan demikian, peneliti bidang pendidikan fisika tertarik untuk mengkaji bagaimana sikap dan pandangan siswa terhadap penyelesaian soal fisika. Hal ini terlihat sejumlah peneliti yang sudah menghasilkan angket untuk mengetahui sikap dan pandangan siswa terhadap fisika (Adams et al., 2006; Mason \& Singh, 2010; Redish, Saul, \& Steinberg, 1998). Salah satu angket sikap pemecahan masalah yang dikembangkan oleh Mason \& Singh (2010) adalah Attitude and Approaches to Problem Solving (AAPS). Angket ini diberikan kepada profesor, mahasiwa sarjana hingga pascasarjana untuk mengetahui sikap mereka ketika menyelesaikan soal fisika. Angket yang sama dengan versi bahasa Turki telah digunakan juga di negara Turki yang diberikan kepada mahasiswa dan siswa sekolah menengah dan kejuruan (Balta, Mason, \& Singh, 2016). Selanjutnya angket penyelesaian soal fisika dalam versi bahasa Indonesia telah dikembangkan oleh Sirait dkk (dalam proses publikasi) yang dikenal dengan Angket Penyelesaian Soal Fisika (APESOFI) dikembangkan dari AAPS. Angket ini diberikan kepada mahasiswa calon guru fisika dari tahun pertama hingga tahun ketiga. Ketiga angket ini berfokus kepada bagaimana siswa, mahasiswa, dan profesor memandang penyelesaian soal fisika.

Penelitian ini bertujuan untuk mengetahui sejauh mana hubungan antara sikap mahasiswa ketika menyelesaikan soal dan hasil belajar fisika. Hal ini perlu dilakukan untuk membantu calon guru fisika dalam menyelesaikan soal fisika karena nantinya mereka akan menghadapi penyelesaian soal ketika mengikuti perkuliahan ataupun dalam menyelesaikan studi mereka. Karena cara pandang mahasiswa terhadap fisika mempengaruhi mereka dalam memahami konsep fisika dan keberhasilan dalam mata kuliah fisika (Wilcox \& Lewandowski, 2017).

\section{METODE PENELITIAN}

Penelitian kuantitatif digunakan dalam studi ini untuk mengetahui hubungan antara sikap mahasiswa ketika mengerjakan soal dan hasil belajar yang melibatkan 60 mahasiswa pendidikan 
fisika (46 orang perempuan dan 14 orang laki-laki) tahun pertama. Umumnya, setelah menyelesaikan kuliah dari program studi ini, mereka akan mengajar di sekolah menengah pertama dan sekolah menengah atas.

Data sikap mahasiswa diperoleh melalui pemberian angket penyelesaian soal fisika (APESOFI) yang dikembangkan oleh Sirait dkk (dalam proses publikasi). Melalui angket ini, sikap atau pandangan mahasiswa ketika menyelesaikan soal fisika dapat diketahui. Angket ini terdiri dari 30 butir pernyataan dengan tujuh indikator yaitu penggunaan representasi, peran matematika dan rumus, memeriksa kembali jawaban, peran konsep, berdiskusi atau bertanya, strategi penyelesaian, dan ketertarikan dan kenyamanan dalam menyelesaikan soal. Selanjutnya, angket tersebut juga memiliki lima pilihan jawaban: sangat setuju, setuju, netral/tidak tahu, tidak setuju, dan sangat tidak setuju.

Angket ini mempunyai pilihan jawaban standar yang sesuai dengan jawaban para ahli dalam menyelesaikan soal fisika. Sehingga, jawaban mahasiswa yang sesuai dengan ahli diberikan skor 1 sedangkan netral atau tidak tahu, tidak sesuai, dan tidak menjawab diberi skor 0. Selanjutnya, data hasil belajar mahasiswa diperoleh dari nilai akhir mata kuliah fisika dasar. Kemudian data yang diperoleh dianalisis secara statistik menggunakan Statistical Package for Social Science Program version 24 (SPSS 24).

\section{HASIL DAN PEMBAHASAN}

TABEL 1 menunjukkan rata-rata skor sikap mahasiswa untuk setiap butir dari angket penyelesaian soal fisika. Untuk pernyataan butir nomor 18 "saya sering membuat coretan pada kertas buram ketika menjawab soal fisika baik dalam bentuk pilihan ganda atau uraian", rata-rata skor yang diperoleh adalah 1 . Itu artinya seluruh mahasiswa setuju dengan pernyataan tersebut atau sesuai dengan sikap yang dilakukan para ahli. Sebanyak tujuh item pernyataan $(4,12,13,14,23,27,28)$ mendapatkan rata-rata skor 0.9. Namun utuk item nomor 1 dan 3, rata-rata skor mahasiswa untuk masing-masing item adalah 0 . Ini menunjukkan bahwa mahasiswa cenderung berhenti berhenti atau tidak melanjutkan penyelesaian soal ketika mereka mengalami kebuntuan (butir 1) dan 100\% mahasiswa memiliki pandangan bahwa matematika menjadi hal yang paling penting untuk mengerjakan soal fisika (butir 3). Selanjutnya, sebanyak 21 item memiliki rata-rata skor di atas 0.5 dan selebihnya 9 pernyataan mendapatkan skor di bawah atau sama dengan 0.5. Secara keseluruhan, rata-rata skor sikap dan pendekatan mahasiswa dalam mengerjakan soal fisika sebesar 0.64. Dengan kata lain, sebesar $64 \%$ mahasiswa memiliki sikap yang sama dengan ahli dalam mengerjakan soal. Berikut adalah rata-rata skor sikap mahasiswa untuk masing-masing indikator.

TABEL 1. Rata-rata skor untuk setiap butir.

\begin{tabular}{llllllllll}
\hline $\mathbf{1}$ & $\mathbf{2}$ & $\mathbf{3}$ & $\mathbf{4}$ & $\mathbf{5}$ & $\mathbf{6}$ & $\mathbf{7}$ & $\mathbf{8}$ & $\mathbf{9}$ & $\mathbf{1 0}$ \\
$\mathbf{0}$ & $\mathbf{0 , 7}$ & $\mathbf{0}$ & $\mathbf{0 , 9}$ & $\mathbf{0 , 5}$ & $\mathbf{0 , 8}$ & $\mathbf{0 , 4}$ & $\mathbf{0 , 6}$ & $\mathbf{0 , 8}$ & $\mathbf{0 , 2}$ \\
& & & & & & & & & \\
$\mathbf{1 1}$ & $\mathbf{1 2}$ & $\mathbf{1 3}$ & $\mathbf{1 4}$ & $\mathbf{1 5}$ & $\mathbf{1 6}$ & $\mathbf{1 7}$ & $\mathbf{1 8}$ & $\mathbf{1 9}$ & $\mathbf{2 0}$ \\
$\mathbf{0 , 2}$ & $\mathbf{0 , 9}$ & $\mathbf{0 , 9}$ & $\mathbf{0 , 9}$ & $\mathbf{0 , 4}$ & $\mathbf{0 , 7}$ & $\mathbf{0 , 6}$ & $\mathbf{1}$ & $\mathbf{0 , 8}$ & $\mathbf{0 , 7}$ \\
& & & & & & & & & \\
$\mathbf{2 1}$ & $\mathbf{2 2}$ & $\mathbf{2 3}$ & $\mathbf{2 4}$ & $\mathbf{2 5}$ & $\mathbf{2 6}$ & $\mathbf{2 7}$ & $\mathbf{2 8}$ & $\mathbf{2 9}$ & $\mathbf{3 0}$ \\
$\mathbf{0 , 8}$ & $\mathbf{0 , 6}$ & $\mathbf{0 , 9}$ & $\mathbf{0 , 8}$ & $\mathbf{0 , 7}$ & $\mathbf{0 , 8}$ & $\mathbf{0 , 9}$ & $\mathbf{0 , 9}$ & $\mathbf{0 , 1}$ & $\mathbf{0 , 7}$ \\
\hline
\end{tabular}

Berdasarkan TABEL 2, diperoleh bahwa menggunakan representasi saat mengerjakan soal dan memeriksa kembali jawaban setelah menyelesaikan soal memiliki rata-rata skor 0,8. Ini menunjukkan bahwa mahasiswa umumnya menggunakan representasi seperti gambar, diagram, dan grafik ketika mengerjakan latihan soal maupun pada saat mengikuti ujian atau tes. Kemudian, mahasiswa juga memeriksa kembali jawaban ketika solusi yang diperoleh tidak masuk akal. Kedua hal ini juga dilakukan oleh para ahli ketika mengerjakan soal fisika. Selanjutnya, peran konsep dalam pemecahan masalah dan manfaat strategi dalam menyelesaian soal mendapatkan rata-rata skor masing-masing 0,7 . 
TABEL 2. Rata-rata skor untuk setiap indikator.

\begin{tabular}{lll}
\hline No & Indikator & Skor \\
\hline 1 & Penggunaan Representasi & 0,8 \\
2 & Peran matematika dan rumus & 0,2 \\
3 & Memeriksa kembali jawaban & 0,8 \\
4 & Peran konsep & 0,7 \\
5 & Berdiskusi dan bertanya & 0,6 \\
6 & Strategi penyelesaian & 0,7 \\
7 & Ketertarikan dan kenyamanan dalam menyelesaikan soal & 0,5 \\
\hline
\end{tabular}

Mahasiswa juga cenderung berdiskusi ketika mengerjakan soal latihan dan bertanya kepada teman sejawat ketika menghadapi kesulitan dalam mengerjakan soal, hal ini ditunjukkan dengan skor 0.6. Kemudian, 50\% mahasiswa menunjukkan sikap yang tertarik dalam mengerjakan soal. Sementara peran matematika dan rumus memiliki skor yang paling rendah dari seluruh indikator yaitu 0.2. Itu artinya mahasiswa menganggap bahwa kemampuan matematika dan rumus merupakan faktor utama untuk dapat mengerjakan soal. Hal ini berbeda dengan pandangan para ahli tentang bagaimana peran matematika dalam penyelesaian soal fisika.

Nilai korelasi masing-masing indikator dan hasil belajar mahasiswa ditunjukkan pada GAMBAR 1 di bawah ini. Hasil analisis menunjukkan bahwa secara keseluruhan korelasi antara sikap dan pendekatan mahasiswa dalam mengerjakan soal fisika dan hasil belajar fisika adalah 0.24. Nilai korelasi ini menunjukkan tidak signifikan secara statistik $(\mathrm{p}=0.06)$. Namun nilai korelasi untuk masing-masing indikator sangat bervariasi. Dua indikator yaitu memeriksa kembali jawaban dan peran konsep dalam menyelesaikan soal memiliki nilai korelasi negatif masing-masing - 0.04 dan $0.02(\mathrm{p}=0.7$ dan $\mathrm{p}=0.8)$. Kemudian nilai korelasi yang paling tinggi dan positif adalah $0.33(\mathrm{p}=$ 0.01) untuk indikator peran strategi dalam menyelesaikan soal. Ini mengindikasikan bahwa faktor strategi yang digunakan mahasiswa dalam mengerjakan soal menjadi salah satu faktor keberhasilan mereka mendapatkan jawaban yang tepat dan benar. Meskipun korelasi indikator penggunaan representasi dan hasil belajar mahasiswa tidak signifikan, namun memiliki korelasi yang cukup tinggi yaitu $0.24(\mathrm{p}=0.06)$.

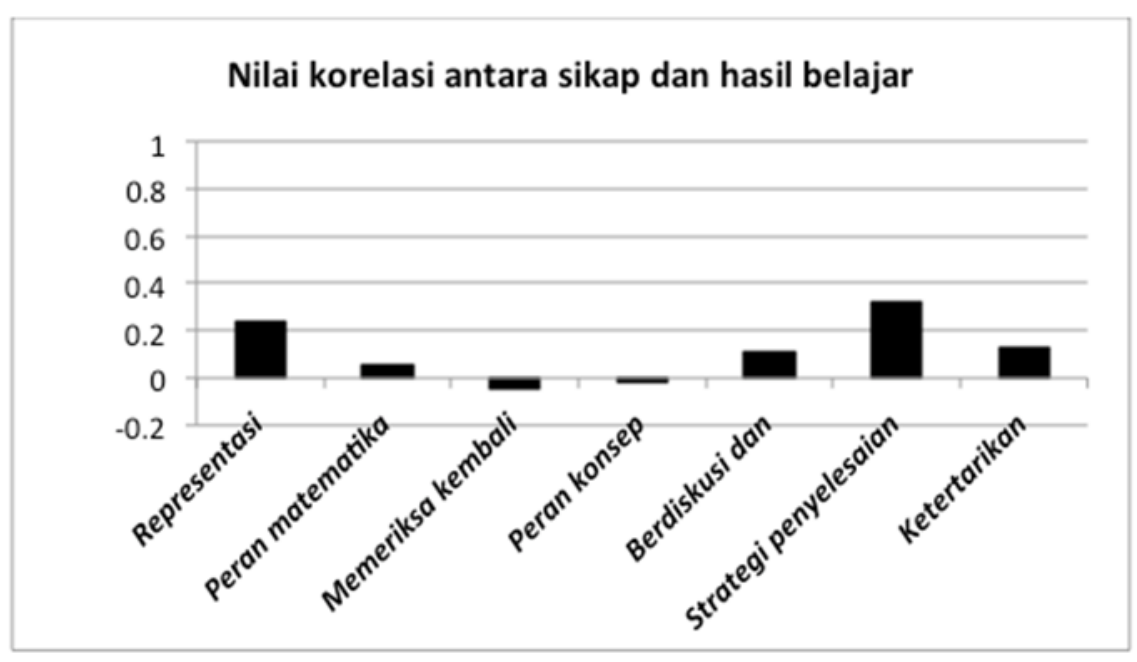

GAMBAR 1. Grafik Nilai korelasi antara sikap dan hasil belajar.

Meskipun secara keseluruhan korelasi antara sikap penyelesaian soal fisika dan hasil belajar mahasiswa tidak signifikan secara statistik, namun salah satu indikator yaitu strategi pemecahan masalah memiliki nilai korelasi yang cukup siginifikan. Salah satu pernyataan pada indikator ini adalah "jika saya menggunakan dua cara/strategi yang berbeda untuk menyelesaikan soal dan jawabannya berbeda, saya akan berpikir lagi untuk memilih cara yang lebih masuk akal." Hampir seluruh mahasiwa setuju dengan pernyataan ini. Hal ini berarti bahwa mahasiswa perlu memiliki pendekatan atau strategi yang bervariasi dalam mengerjakan sebuah soal. Misalnya ketika diminta mengerjakan soal usaha dan energi, mahasiswa bisa menggunakan pendekatan lewat hukum Newton 
atau momentum. Disamping itu, para ahli telah memperkenalkan beberapa strategi pemecahan masalah diantaranya penyelesaian soal secara kualitatif (Leonard et al., 1996), penyelesaian soal secara konseptual (Docktor et al., 2015), penyelesaian soal secara explisit (Huffman, 1997), dan lima langkah dalam menyelesaian soal (Heller et al., 1992). Pernyataan lain juga menunjukkan bahwa ketika satu cara atau strategi tidak berhasil, mahasiswa memilih untuk mencari cara lain. Ketika mahasiswa memiliki beberapa strategi dalam mengerjakan soal fisika, kemampuan ini juga akan bisa digunakan ketika mereka akan menjadi guru fisika di sekolah.

Menggunakan representasi juga memiliki korelasi yang tinggi meskipun tidak signifikan. Ini berarti bahwa penggunaan representasi memberikan kontribusi dalam keberhasilan mahasiswa dalam mengerjakan soal. Mahasiswa sering membuat sketsa: gambar, grafik, diagram, dll berdasarkan situasi atau permasalahan yang diberikan (item nomor 2). Kemudian mereka juga membuat gambar atau grafik ketika mengerjakan soal pilihan ganda ataupun uraian baik pada saat latihan soal dan ujian meskipun tidak ada skor tambahan yang diberikan oleh dosen. Seperti yang dikemukakan oleh Disessa, Hammer, Sherin, dan Kolpakowski (1991) bahwa ketika siswa diberi kesempatan untuk membuat representasi sendiri dari pengetahuan sebelumnya, siswa cenderung lebih mudah untuk memahami konsep. Selanjutnya, sejumlah peneliti mengatakan bahwa mahasiswa yang diajar menggunakan representasi dapat meningkatkan kemampuan pemahan konsep (Haratua \& Sirait, 2015; Rosengrant, Van Heuvelen, \& Etkina, 2009; Savinainen, Mäkynen, Nieminen, \& Viiri, 2013; Van Heuvelen \& Zou, 2001). Penggunaan representasi menjadi salah satu kemampuan dalam belajar fisika dan pada saat menyelesaikan soal fisika (McPadden \& Brewe, 2017). Hal ini didukung oleh penelitian Sirait, Hamdani, dan Oktavianty (2017) yang menyatakan bahwa mahasiswa harus memiliki kemampuan representasi vektor ketika menyelesaikan soal gaya.

\section{SIMPULAN}

Hasil penelitian ini menunjukkan bahwa sikap mahasiswa ketika menyelesaikan soal dapat mempengaruhi keberhasilan mereka dalam menyelesaikan mata kuliah fisika dasar karena mereka berkecimpung dalam penyelesaian soal pada saat mengambil mata kuliah tersebut. Salah satu indikator yang cukup berpengaruh adalah strategi yang mereka gunakan ketika menyelesaikan soal. Kemampuan menyelesaikan soal menjadi salah satu kompetensi yang dimiliki oleh calon guru fisika. Studi selanjutnya perlu dikaji dengan memberikan langsung soal kepada mahasiswa setelah mereka mengisi angket tersebut untuk melihat kesesuaian sikap dan jawaban pada saat menyelesaikan soal.

\section{UCAPAN TERIMAKASIH}

Ucapan terimakasih kepada Kementrian Riset Tekonologi dan Pendidikan Tinggi (KEMENRISTEKDIKTI) melalui dana Penelitian Kerjasama Antar Perguruan Tinggi (PEKERTI) yang diberikan untuk melaksanakan penelitian ini. Tidak lupa juga ucapan terimakasih kepada mahasiswa dan Progam Studi Pendidikan Fisika yang sudah mendukung penelitian ini.

\section{REFERENSI}

Adams, W. K., Perkins, K. K., Podolefsky, N. S., Dubson, M., Finkelstein, N. D., \& Wieman, C. E. (2006). New instrument for measuring student beliefs about physics and learning physics: The colorado learning attitudes about science survey. Physical Review Special Topics - Physics Education Research, 2(1), pp. 1-14.

Balta, N., Mason, A., \& Singh, C. (2016). Surveying turkish high school and university student attitudes and approaches to physics problem solving. Physical Review Physics Education Research, 12(1), pp. 1-16.

Ding, L., \& Zhang, P. (2016). Making of epistemologically sophisticated physics teachers: A crosssequential study of epistemological progression from preservice to in-service teachers. Physical Review Physics Education Research, 12(2), pp. 1-16. 
Disessa, A. A., Hammer, D., Sherin, B., \& Kolpakowski, T. (1991). Inventing graphing: Metarepresentationa expertise in children. Journal of Mathematical Behaviour, 10, pp.117-160.

Docktor, J. L., Strand, N. E., Mestre, J. P., \& Ross, B. H. (2015). Conceptual problem solving in high school physics. Physical Review Special Topics - Physics Education Research, 11(2), pp. 1-13.

Elby, A. (2001). Helping physics students learn how to learn. American Journal of Physics, 69(1), pp. 54-64.

Hammer, D. (1994). Students' beliefs about conceptual knowledge in introductory physics. International Journal of Science Education, 16(4), pp. 385-403.

Haratua, T., \& Sirait, J. (2015). Representations based physics instruction to enhance students' problem solving. American Journal of Educational Research, 4(1), pp. 1-4.

Heller, P., Keith, R., \& Anderson, S. (1992). Teaching problem solving through cooperative grouping. part 1: Group versus individual problem solving. American Journal of Physics, 60(7), pp. 627-636.

Hestenes, D., Wells, M., \& Swackhamer, G. (1992). Force concept inventory. The Physics Teacher, 30(3), pp. 141-158.

Huffman, D. (1997). Effect of explicit problem solving instruction on high school students' problemsolving performance and conceptual understanding of physics. Journal of Research in Science Teaching, 34(6), pp. 551-570.

Kuo, E., Hull, M. M., Gupta, A., \& Elby, A. (2013). How students blend conceptual and formal mathematical reasoning in solving physics problems. Science Education, 97(1), pp. 32-57.

Leonard, W. J., Dufresne, R. J., \& Mestre, J. P. (1996). Using qualitative problem-solving strategies to highlight the role of conceptual knowledge in solving problems. American Journal of Physics, 64(12), pp. 1495-1503.

Mason, A., \& Singh, C. (2010). Surveying graduate students' attitudes and approaches to problem solving. Physical Review Special Topics - Physics Education Research, 6(2), pp. 1-16.

May, D. B., \& Etkina, E. (2002). College physics students' epistemological self-reflection and its relationship to conceptual learning. American Journal of Physics, 70(12), pp. 1249-1258.

McPadden, D., \& Brewe, E. (2017). Impact of the second semester\&nbsp;university modelling instruction course on students' representation choice\&nbsp; Physical Review Physics Education Research, 13(2), pp. 1-15.

Mestre, J. P., Docktor, J. L., Strand, N. E., \& Ross, B. H. (2011). Conceptual problem solving in physics. Psychology of learning and motivation, 55, pp. 269-298.

Redish, E. F., Saul, J. M., \& Steinberg, R. N. (1998). Student expectations in introductory physics. American Journal of Physics, 66(3), pp. 212-224.

Rosengrant, D., Van Heuvelen, A., \& Etkina, E. (2009). Do students use and understand free-body diagrams? Physical Review Special Topics - Physics Education Research, 5(1), pp.1-13.

Savinainen, A., Mäkynen, A., Nieminen, P., \& Viiri, J. (2013). Does using a visual-representation tool foster students' ability to identify forces and construct free-body diagrams? Physical Review Special Topics - Physics Education Research, 9(1), pp. 1-11.

Sirait, J., Hamdani, \& Oktavianty, E. (2017). Analysis of pre-service physics teachers' understanding of vectors and forces. Journal of Turkish Science Education, 13(2), pp. 82-95.

Van Heuvelen, A., \& Zou, X. (2001). Multiple representations of work-energy processes. American Journal of Physics, 69(2), pp.184-194.

Wilcox, R. B., \& Lewandowski, H. J. (2017). Students' views about the nature of experimental physics. Physical Review Physics Education Research, 13(2), pp. 1-10. 